\title{
ANALISIS KEMAMPUAN PEMECAHAN MASALAH MATEMATIKA SISWA SMP NEGERI 10 TANGERANG
}

\author{
${ }^{1}$ Novitasari, ${ }^{2}$ Hestu Wilujeng \\ ${ }^{1}$ SMAN 9 Tangerang, Jl. H.Jali No.9, Pinang, Kota Tangerang, Banten, (021) 22261424 \\ ${ }^{2}$ Universitas Muhammadiyah Tangerang, Jl. Perintis Kemerdekaan I/33, Cikokol, Kota Tangerang, Banten, \\ (021) 5539532 \\ e-mail : novi.novitasari22@gmail.com
}

\begin{abstract}
Abstrak
Penelitian ini merupakan penelitian deskriptif kualitatif. Subjek penelitian adalah siswa kelas VIII SMP Negeri 10 Tangerang. Data yang diperoleh dari penelitian ini adalah data uji kemampuan pemecahan masalah matematika seperti tes tulis dan wawancara. Analisis data dilakukan berdasarkan hasil uji tulis dan wawancara, kemudian dilakukan teknik triangulasi untuk mendapatkan data penelitian yang valid. Hasilnya menunjukkan bahwa siswa yang memiliki kemampuan tinggi, baik laki-laki maupun perempuan mampu memahami masalahnya dengan baik, memiliki rencana pemecahan dan dapat menyelesaikan penyelesaian masalah sesuai dengan rencana dan dapat melakukan pengecekan ulang. Sedangkan siswa yang memiliki kemampuan menengah, baik laki-laki maupun perempuan hampir memiliki kemampuan yang sama dengan siswa yang memiliki kemampuan tinggi, bedanya hanya pada langkah-langkah untuk memecahkan masalah dan pengecekan ulang. Siswa yang memiliki kemampuan menengah kurang memahami perhitungan dalam jumlah operasi, jadi ada kesalahan dalam proses perhitungan yang hasilnya tidak benar dan dalam aspek pengecekan, siswa yang memiliki kemampuan menengah hanya memeriksa sebagian saja. Lain kasus siswa yang memiliki kemampuan rendah. Siswa yang memiliki kemampuan rendah, baik laki-laki maupun perempuan tidak bisa menyelesaikan masalah secara tuntas, karena belum mengetahui rencana penyelesaian yang belum matang, jadi tidak ada hasilnya. Sedangkan pada aspek pengecekan, siswa yang memiliki kemampuan rendah hanya melihat proses perhitungan, tidak mengecek hasilnya benar atau salah, karena siswa yang memiliki kemampuan rendah tidak ada hasilnya, sehingga mereka tidak mengecek hasil yang diperoleh.
\end{abstract}

Kata Kunci : kemampuan pemecahan masalah

\begin{abstract}
This research is a descriptive qualitative research. The research subject were eight-one grade students of SMP Negeri 10 Tangerang. Data obtained from this research is the test data in ability of mathematical problem solving like writing test and interview. Data analysis is done based on the result of writing test and interview, then it is done by triangulation techniques to obtain valid research data. The result showed that students who have the high ability, both men and women are able to understand the problem very well, has a split plan and can finish the problem resolution is suitable as the plan and be able to re-check. While students who have the middle ability, both men and women is almost have the same ability as students who have the high ability, the difference is only in the steps to solve the problem and re-checking. Student who have the middle ability are less to understand the calculations in number operations, so there is an error in the calculation process that the result obtained is not correct and in the checking aspect, students who have the middle ability are only check a part. Another case of students who have the low ability. Students who have the low ability, both men and women can not solve the problem completely, because the have not know the plan prosedures cleary yet, so do not have the result obtained. While in the checking aspect, students who have a low ability only see the calculation process, does not check the result is correct or wrong, because of the students who have the low ability are not have any result, so they do not recheck the result obtained.
\end{abstract}

Keywords : the ability of mathematical problem solving

\section{PENDAHULUAN}

Matematika merupakan salah satu pelajaran yang mempunyai peran penting dalam kehidupan khususnya dalam dunia pendidikan. Karena tujuan diberikannya matematika antara lain agar siswa mampu menghadapi perubahan keadaan di dunia yang selalu berkembang, 
melalui latihan bertindak atas dasar pemikiran secara logis, kritis dan rasional sehingga membentuk kepribadian yang kreatif dan mempunyai keberanian untuk menghadapi masalahmasalah dalam kehidupan sehari-hari. Hal tersebut senada dengan pendapat Wena (2011) yang menyatakan bahwa hakikat tujuan pembelajaran tidak hanya memahami dan menguasai apa dan bagaimana suatu hal bisa terjadi, tetapi juga memberi pemahaman dan pengetahuan tentang "mengapa hal itu terjadi". Pernyataan tersebut menunjukan bahwa siswa tidak hanya memahami materi apa yang disampaikan dan bagaimana menyelesaikan masalah yang berkaitan dengan materi tersebut, tetapi siswa perlu mengetahui mengapa materi tersebut disampaikan atau dengan kata lain siswa memahami pentingnya materi tersebut untuk disampaikan.

Kegiatan pembelajaran matematika tidak akan pernah lepas dari masalah matematika, karena matematika merupakan salah satu pelajaran yang berkaitan dengan pemecahan masalah. Matematika merupakan salah satu mata pelajaran yang mempunyai peranan penting dalam memenuhi kebutuhan praktis dan memecahkan masalah dalam kehidupan sehari-hari. Siswa diharapkan dapat memiliki kemampuan pemecahan masalah dan mengembangkannya untuk menghadapi masalah yang dialami dalam kehidupannya, sehingga kemampuan pemecahan masalah sangat penting untuk dimiliki oleh siswa. Dalam jurnal pendidikan IndoMS J.M.E (Sugiman dan Yaya, 2010) menyatakan bahwa kemampuan pemecahan masalah matematika sangat dibutuhkan oleh masyarakat. Mengingat pentingnya peran pemecahan masalah, maka pemecahan masalah menjadi fokus dalam pembelajaran matematika di berbagai negara. Pemecahan masalah bukan sekedar tujuan dari pembelajaran matematika, tetapi juga sebagai keterampilan untuk mengambil keputusan yang terbaik dalam kehidupan.

Salah satu penelitian yang menjadi perhatian besar bagi para akademisi, praktisi dan pemerhati pendidikan matematika yaitu penelitian Trends in International Mathematics and Science Study (TIMSS). Berdasarkan laporan TIMSS, ranking Indonesia pada tahun 1999 berada pada ranking bawah, yaitu 34 dari 38 negara. Kemudian pada tahun 2003, Indonesia menempati ranking 35 dari 46 negara dan pada tahun 2007, Indonesia menempati ranking 36 dari 49 negara. Sedangkan pada tahun 2011, para siswa kelas VIII Indonesia menempati posisi ke 38 diantara 42 negara yang berpartisipasi dalam tes matematika. Dari rata-rata skor internasional 500, para siswa Indonesia hanya memperoleh skor rata-rata 386. Rata-rata skor tersebut menunjukkan kemampuan matematika para siswa Indonesia berada pada tingkatan yang rendah (low) di antara empat tingkatan lainnya, yaitu lanjut (advanced), tinggi (high), dan menengah (intermediate).

Prima, Vol. 2, No. 2, Juli 2017, 137 - 147. 
Rendahnya kemampuan memecahkan masalah matematika terjadi pada siswa di SMP Negeri 10 Tangerang. Pada umumnya, siswa belum memahami masalah yang disajikan, karena keterbiasaan siswa dalam mengerjakan soal-soal rutin. Selain itu, ada beberapa siswa yang dapat memahami masalah dan mengerjakan sesuai langkah-langkahnya, tetapi tidak melalukan pengecekan kembali, sehingga hasilnya kurang tepat. Sulitnya siswa dalam memecahkan masalah matematika, terutama pada soal-soal yang memerlukan pemikiran tingkat tinggi dipengaruhi oleh banyak faktor yang saling terkait, baik dari dalam diri siswa (internal) maupun dari luar diri siswa (eksternal). Faktor yang terjadi dalam diri siswa adalah kurang pahamnya dengan materi yang diajarkan, kemudian malu untuk bertanya kepada gurunya bahkan tidak ada inisiatif untuk bertanya ke temannya sendiri yang lebih menguasai. Faktor yang terjadi di luar diri siswa adalah metode pembelajaran yang digunakan guru, tes yang digunakan masih tingkat rendah, dan lingkungan siswa yang tidak kondusif.

Kemampuan dalam memecahkan masalah matematika setiap siswa dimungkinkan memiliki derajat yang berbeda-beda. Kemampuan pemecahan masalah siswa laki-laki mungkin berbeda dengan siswa perempuan dan kemampuan pemecahan masalah siswa yang berkemampuan tinggi mungkin berbeda dengan siswa yang berkemampuan sedang ataupun yang berkemampuan rendah.

Berdasarkan latar belakang yang telah diungkapkan di atas, maka peneliti melakukan penelitian yang berjudul "Analisis Kemampuan Pemecahan Masalah Matematika Siswa SMP Negeri 10 Tangerang".

\section{Tinjauan Teoritis}

Pemecahan masalah adalah suatu upaya yang dilakukan untuk menyelesaikan permasalahan yang ditemukan. Pemecahan masalah merupakan bagian yang sangat penting dalam matematika. Hal ini senada dengan pendapat Suherman (2003) yang menyatakan bahwa pemecahan masalah merupakan bagian dari kurikulum matematika yang sangat penting karena dalam proses pembelajaran maupun penyelesaiannya, siswa dimungkinkan memperoleh pengalaman menggunakan pengetahuan serta keterampilan yang sudah dimiliki untuk diterapkan pada pemecahan masalah yang bersifat tidak rutin. Aspek-aspek kemampuan matematika penting seperti aturan penerapan pada masalah tidak rutin, penemuan pola, penggeneralisasian, komunikasi matematika, dan lain-lain dapat dikembangkan secara lebih baik. 
Dalam belajar matematika, siswa mengalami kesulitan khususnya dalam menyelesaikan soal yang berhubungan dengan pemecahan masalah matematika. Pada umumnya, kemampuan siswa dalam menyelesaikan masalah matematika belum memuaskan. Untuk itu kemampuan pemecahan masalah dalam matematika perlu dilatih dan dibiasakan sedini mungkin kepada siswa. Kemampuan ini sangat diperlukan siswa sebagai bekal dalam memecahkan masalah yang ditemukan dalam kehidupan sehari-hari.

Kemampuan pemecahan masalah amatlah penting, bukan saja bagi mereka yang kemudian hari akan mendalami matematika, melainkan juga bagi mereka yang akan menerapkannya, baik dalam bidang studi lain maupun dalam kehidupan sehari-hari. Jika seseorang telah menemukan pemecahan dari suatu masalah maka masalah tersebut bukan lagi masalah bagi dirinya, tetapi belum tentu bukan merupakan masalah bagi orang lain.

Berdasarkan uraian yang telah diungkapkan di atas, maka dapat disimpulkan bahwa kemampuan pemecahan masalah matematika adalah kesanggupan untuk mencari jalan keluar dari sebuah kondisi di mana seseorang tidak mengetahui penyelesaiannya secara langsung dengan menggabungkan konsep-konsep dan aturan-aturan matematika yang telah diperoleh sebelumnya.

Polya mengemukakan bahwa langkah-langkah pemecahan masalah matematika terdiri dari 4 langkah (Budhayanti, 2008, h.9-9), yaitu:

\section{Memahami masalah (understand the problem)}

Langkah ini sangat menentukan kesuksesan memperoleh solusi masalah. Langkah ini melibatkan pendalaman situasi masalah, melakukan pemilihan fakta-fakta, menentukan hubungan di antara fakta-fakta, dan membuat formulasi pertanyaan masalah. Setiap masalah yang tertulis, bahkan yang rendah sekalipun harus dibaca berulang kali dan informasi yang terdapat dalam masalah harus dipelajari dengan seksama. Karena tanpa adanya pemahaman terhadap masalah yang diberikan, siswa tidak mungkin mampu menyelesaikan masalah tersebut dengan benar.

Kegiatan yang dapat dilakukan pada langkah ini adalah apa (data) yang diketahui, apa yang tidak diketahui (ditanyakan), apakah informasi cukup, kondisi (syarat) apa yang harus dipenuhi, menyatakan kembali masalah asli dalam bentuk yang lebih operasional (dapat dipecahkan). Oleh karena itu pada langkah ini, siswa harus mengetahui masalah secara jelas apa yang diketahui dan ditanyakan. Tanpa adanya pemahaman terhadap masalah yang diberikan, siswa tidak mungkin mampu menyelesaikan masalah tersebut dengan benar. 
2. Merencanakan pemecahannya (devising a plan)

Langkah ini perlu dilakukan dengan percaya diri ketika masalah sudah dapat dipahami. Rencana solusi dibangun dengan mempertimbangkan struktur masalah dan pertanyaan yang harus dijawab. Rencana harus melihat berbagai unsur yang dapat dihubungkan. Hal ini diperlukan sebagai gagasan untuk menyelesaikan masalah yang memerlukan kemampuan. Kemampuan melakukan langkah kedua ini sangat tergantung pada pengalaman siswa dalam menyelesaikan masalah. Pada umumnya semakin bervariasi pengalaman mereka, ada kecenderungan siswa lebih kreatif dalam menyusun rencana penyelesaian suatu masalah.

Kegiatan yang dapat dilakukan pada langkah ini adalah mencoba mencari atau mengingat masalah yang pernah diselesaikan yang memiliki kemiripan dengan masalah yang akan dipecahkan, mencari pola atau aturan, menyusun prosedur penyelesaian (membuat konjektur).

3. Menyelesaikan masalah sesuai rencana (carry out a plan)

Untuk mencari solusi yang tepat, rencana yang sudah dibuat baik tertulis ataupun tidak pada langkah kedua harus dilaksanakan dengan hati-hati. Oleh karena itu, siswa dituntut terampil dalam berhitung, memanipulasi aljabar dan membuat penjelasan dalam memecahkan masalah tersebut. Selain itu, siswa dituntut memiliki kemampuan memahami konsep yang terkait dengan model matematika. Kegiatan yang dapat dilakukan pada langkah ini adalah menjalankan prosedur yang telah dibuat pada langkah sebelumnya untuk mendapatkan penyelesaian.

4. Melakukan pengecekan kembali terhadap semua langkah yang telah dikerjakan.

Langkah ini merupakan langkah akhir untuk memastikan hasil yang paling tepat. Selama berlangsungnya langkah ini solusi masalah harus dipertimbangkan dengan pengecekan ulang perhitungannya. Kegiatan yang dapat dilakukan pada langkah ini adalah menganalisis dan mengevaluasi apakah prosedur yang diterapkan dan hasil yang diperoleh benar, atau apakah prosedur dapat dibuat generalisasinya. Untuk dapat melakukan tahap ini dengan baik, maka perlu latihan mengenai :

a. Memeriksa penyelesaian jawaban.

b. Memeriksa apakah jawaban yang diperoleh masuk akal.

c. Memeriksa pekerjaan, adakah perhitungan atau analisis yang salah.

d. Memeriksa pekerjaan, adakah yang kurang lengkap atau kurang jelas. 


\section{METODE PENELITIAN}

Jenis penelitian ini adalah penelitian kualitatif deskriptif. Subjek penelitian terdiri dari 3 siswa perempuan dan 3 siswa laki laki yang masing-masing memiliki kemampuan tinggi, sedang dan rendah serta masing-masing subjek dikodekan. Huruf pertama menunjukkan jenis kelamin dan huruf yang kedua menunjukkan tingkat kemampuannya. Instrumen penelitian ini adalah soal yang berbentuk masalah dan pedoman wawancara. Pengumpulan data pada penelitian ini dilakukan dengan menggunakan beberapa teknik yaitu observasi berupa gerakgerik dan ekspresi siswa dalam menyelesaikan masalah, wawancara dan studi dokumen yang berupa tes tulis dan arsip nilai rapor matematika untuk menentukan subjek penelitian. Masingmasing subjek diberikan soal dan diwawancara, kemudian dianalisis untuk mendeskripsikan kemampuannya dalam memecahkan masalah. Analisis yang dilakukan berupa mereduksi data, menyajikan atau memaparkan data dan menarik kesimpulan.

Selanjutnya untuk mengecek keabsahan data digunakan uji credibility, uji transferability, uji dependability, dan uji confirmability. Dalam penelitian ini, uji kredibilitas yang digunakan adalah triangulasi teknik. Triangulasi teknik dilakukan dengan cara membandingkan hasil tes tertulis soal pemecahan masalah 1 dengan hasil wawancara dan hasil tes tertulis soal pemecahan masalah 2 dengan hasil wawancara. Jika kedua hasil tes tertulis soal pemecahan masalah dan wawancara tersebut sudah memiliki kesesuaian yang sama maka data siap dianalisis. Jika belum maka perlu tes soal pemecahan masalah 3.

\section{HASIL DAN PEMBAHASAN}

Berikut ini disajikan hasil penelitian tentang kemampuan pemecahan masalah matematika siswa.

Tabel 1

Kemampuan Pemecahan Masalah Matematika Siswa Laki-Laki

\begin{tabular}{|c|c|c|c|}
\hline \multirow{2}{*}{$\begin{array}{c}\text { Aspek } \\
\text { Kemampuan } \\
\text { Pemecahan } \\
\text { Masalah } \\
\end{array}$} & \multicolumn{3}{|c|}{ Laki-laki } \\
\hline & Tinggi & Sedang & Rendah \\
\hline $\begin{array}{c}\text { Memahami } \\
\text { masalah }\end{array}$ & $\begin{array}{l}\text { 1. Membaca soal dengan fokus } \\
\text { tanpa suara dan mampu } \\
\text { menterjemahkan informasi ke } \\
\text { dalam model matematika } \\
\text { dengan cepat. } \\
\text { 2. Mengetahui informasi yang } \\
\text { ada, baik informasi yang } \\
\text { diketahui maupun yang } \\
\text { ditanyakan. }\end{array}$ & $\begin{array}{l}\text { 1. Membaca soal dengan } \\
\text { fokus dan bersuara } \\
\text { sebanyak dua kali. } \\
\text { 2. Mengetahui informasi ada, } \\
\text { baik informasi yang } \\
\text { diketahui maupun yang } \\
\text { ditanyakan. } \\
\text { 3. Menuliskan informasi yang } \\
\text { diketahui dan yang } \\
\text { ditanyakan ke dalam model } \\
\text { matematika. }\end{array}$ & $\begin{array}{l}\text { 1. Membaca soal dengan bersuara } \\
\text { dan kurang fokus sehingga } \\
\text { membutuhkan waktu yang lama } \\
\text { untuk menterjemahkan } \\
\text { informasi ke dalam model } \\
\text { matematika. } \\
\text { 2. Mengetahui informasi yang ada, } \\
\text { baik informasi yang diketahui } \\
\text { maupun yang ditanyakan. } \\
\text { 3. Menuliskan informasi yang } \\
\text { diketahui, namun tidak }\end{array}$ \\
\hline
\end{tabular}

Prima, Vol. 2, No. 2, Juli 2017, 137 - 147. 


\begin{tabular}{|c|c|c|c|}
\hline & $\begin{array}{l}\text { ditanyakan ke dalam model } \\
\text { matematika. } \\
\text { 4. Dapat membuat kaitan antara } \\
\text { informasi yang diketahui dan } \\
\text { yang ditanyakan. } \\
\text { 5. Mengetahui bahwa informasi } \\
\text { yang ada sudah cukup untuk } \\
\text { menyelesaikan masalah. }\end{array}$ & $\begin{array}{lr}\text { 4. Dapat membuat } & \text { kaitan } \\
\text { antara informasi } & \text { yang } \\
\text { diketahui dan yang } & \text { ditanyakan. } \\
\text { 5. Mengetahui } \quad \text { bahwa } \\
\text { informasi yang ada sudah } \\
\text { cukup untuk menyelesaikan } \\
\text { masalah masalah. }\end{array}$ & $\begin{array}{l}\text { menuliskan informasi yang } \\
\text { ditanyakan. } \\
\text { 4. Tidak dapat membuat kaitan } \\
\text { antara informasi yang diketahui } \\
\text { dan yang ditanyakan. } \\
\text { 5. Mengetahui bahwa informasi } \\
\text { yang ada sudah cukup untuk } \\
\text { memecahkan masalah. }\end{array}$ \\
\hline & $\begin{array}{l}\text { 1. Terdiam sambil memegang } \\
\text { kepalanya setelah } \\
\text { menemukan dua buah } \\
\text { persamaan. } \\
\text { 2. Menggunakan rumus logik } \\
\text { untuk memecahkan } \\
\text { masalahnya karena dianggap } \\
\text { lebih mudah, namun tidak } \\
\text { dituliskan secara tertulis } \\
\text { rumus tersebut. } \\
\text { 3. Mengetahui rumus lain yang } \\
\text { dapat digunakan selain rumus } \\
\text { logik. }\end{array}$ & $\begin{array}{l}\text { 1. Berpikir sambil menggaruk- } \\
\text { garukan kepalanya, tidak } \\
\text { lama kemudian langsung } \\
\text { mengerjakannya. } \\
\text { 2. Menggunakan rumus logik } \\
\text { yang dianggapnya lebih } \\
\text { mudah, tetapi tidak } \\
\text { menuliskan rumus tersebut. } \\
\text { 3. Mengetahui rumus lain } \\
\text { yang dapat digunakan selain } \\
\text { rumus logik. }\end{array}$ & $\begin{array}{l}\text { 1. Melihat ke atas sambil } \\
\text { bergumam dan menggeleng- } \\
\text { gelengkan kepalanya. } \\
\text { 2. Menggunakan rumus logik yang } \\
\text { dianggapnya lebih mudah, } \\
\text { tetapi tidak menuliskan rumus } \\
\text { tersebut. } \\
\text { 3. Tidak mengetahui rumus lain } \\
\text { yang dapat digunakan selain } \\
\text { rumus logik. }\end{array}$ \\
\hline $\begin{array}{l}\text { Menyelesaikan } \\
\text { masalah sesuai } \\
\text { rencana }\end{array}$ & $\begin{array}{l}\text { 1. Fokus dan melakukan corat- } \\
\text { coret di kertas lain ketika } \\
\text { menghitung. } \\
\text { 2. Mampu menyelesaikan } \\
\text { masalah dengan benar dan } \\
\text { tepat. } \\
\text { 3. Langkah-langkah yang } \\
\text { digunakan sesuai dengan } \\
\text { rencananya. }\end{array}$ & $\begin{array}{l}\text { 1. Tertib dalam } \\
\text { mengerjakannya, tetapi } \\
\text { terkadang melihat ke atas } \\
\text { sambil berpikir. } \\
\text { 2. Dapat menyelesaikan } \\
\text { masalah } \\
\text { 3. Langkah-langkah yang } \\
\text { disusun sesuai dengan } \\
\text { rencana sebelumnya, tetapi } \\
\text { masih ada kekeliruan pada } \\
\text { perhitungannya. }\end{array}$ & $\begin{array}{l}\text { 1. Tidak fokus dan putus asa } \\
\text { karena merasa sudah tidak } \\
\text { sanggup lagi untuk } \\
\text { mengerjakannya. } \\
\text { 2. Tidak dapat menyelesaikan } \\
\text { masalah secara tuntas, hanya } \\
\text { sebagian yang dikerjakan. } \\
\text { 3. Langkah-langkah yang } \\
\text { diterapkan belum sesuai } \\
\text { rencananya. }\end{array}$ \\
\hline $\begin{array}{c}\text { Melakukan } \\
\text { pengecekan } \\
\text { kembali } \\
\text { terhadap } \\
\text { semua langkah } \\
\text { yang } \\
\text { dikerjakan }\end{array}$ & $\begin{array}{l}\text { 1. Melihat kembali proses } \\
\text { penyelesaian yang dilakukan } \\
\text { sambil berhitung } \\
\text { dipikirannya. } \\
\text { 2. Mensubtitusikan nilai x dan y } \\
\text { ke persamaan yang telah di } \\
\text { dapat sebelumnya, tetapi tidak } \\
\text { melakukan pengecekan secara } \\
\text { tertulis, menghitungnya } \\
\text { dipikirannya saja. }\end{array}$ & 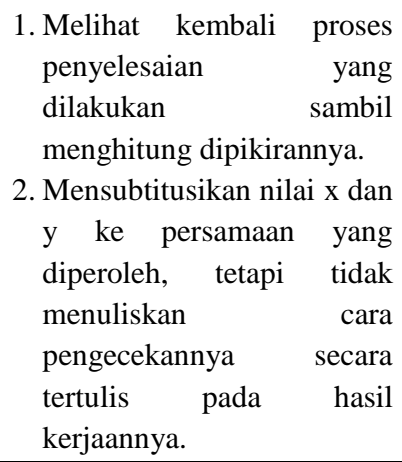 & $\begin{array}{l}\text { 1. Melihat kembali proses } \\
\text { penyelesaian yang dilakukan } \\
\text { sambil menggerak-gerakan } \\
\text { pulpen yang dipegangnya. } \\
\text { 2. Merasa bingung melakukan } \\
\text { pengecekannya karena belum } \\
\text { mempunyai hasil. }\end{array}$ \\
\hline
\end{tabular}

Tabel 2

Kemampuan Pemecahan Masalah Matematika Perempuan

\begin{tabular}{|c|c|c|c|}
\hline \multirow{2}{*}{$\begin{array}{c}\text { Aspek } \\
\text { Kemampuan } \\
\text { Pemecahan } \\
\text { Masalah } \\
\end{array}$} & \multicolumn{3}{|c|}{ Perempuan } \\
\hline & Tinggi & Sedang & Rendah \\
\hline $\begin{array}{c}\text { Memahami } \\
\text { masalah }\end{array}$ & $\begin{array}{l}\text { 1. Membaca soal dengan fokus } \\
\text { namun bersuara sebanyak dua } \\
\text { kali dan mampu } \\
\text { menterjemahkan informasi } \\
\text { yang ada ke dalam model } \\
\text { matematika dengan cepat. } \\
\text { 2. Mengetahui informasi yang } \\
\text { ada, baik informasi yang }\end{array}$ & $\begin{array}{l}\text { 1. Membaca soal dengan } \\
\text { fokus tanpa suara dan cukup } \\
\text { cepat dalam } \\
\text { menterjemahkan kalimat } \\
\text { menjadi model matematika. } \\
\text { 2. Mengetahui informasi yang } \\
\text { ada, baik informasi yang } \\
\text { diketahui maupun yang } \\
\text { ditanyakan. }\end{array}$ & $\begin{array}{l}\text { 1. Membaca soal di dalam hati dan } \\
\text { membutuhkan waktu yang lama } \\
\text { untuk menterjemahkan kalimat } \\
\text { ke dalam model matematika. } \\
\text { 2. Mengetahui informasi yang ada, } \\
\text { baik informasi yang diketahui } \\
\text { maupun yang ditanyakan. } \\
\text { 3. Menuliskan informasi yang } \\
\text { diketahui, tetapi tidak }\end{array}$ \\
\hline
\end{tabular}




\begin{tabular}{|c|c|c|c|}
\hline & $\begin{array}{l}\text { diketahui maupun yang } \\
\text { ditanyakan. } \\
\text { 3. Menuliskan informasi yang } \\
\text { diketahui dan yang } \\
\text { ditanyakan. } \\
\text { 4. Dapat membuat kaitan antara } \\
\text { informasi yang diketahui dan } \\
\text { yang ditanyakan. } \\
\text { 5. Mengetahui bahwa informasi } \\
\text { yang ada sudah cukup untuk } \\
\text { memecahkan masalah. }\end{array}$ & $\begin{array}{l}\text { 3. Menuliskan informasi yang } \\
\text { diketahui dan yang } \\
\text { ditanyakan. } \\
\text { 4. Dapat membuat kaitan } \\
\text { antara informasi yang } \\
\text { diketahui dan yang } \\
\text { ditanyakan. } \\
\text { 5. Mengetahui bahwa } \\
\text { informasi yang ada sudah } \\
\text { cukup untuk memecahkan } \\
\text { masalah. }\end{array}$ & $\begin{array}{l}\text { menuliskan informasi yang } \\
\text { tanyakan. } \\
\text { 4. Tidak dapat membuat kaitan } \\
\text { antara informasi yang diketahui } \\
\text { dan yang ditanyakan } \\
\text { 5. Mengetahui bahwa informasi } \\
\text { yang ada sudah cukup untuk } \\
\text { memecahkan masalah. }\end{array}$ \\
\hline $\begin{array}{l}\text { Merencanakan } \\
\text { pemecahannya }\end{array}$ & $\begin{array}{l}\text { 1. Melihat ke atas sambil } \\
\text { menggerak-gerakan pulpen } \\
\text { yang dipegangnya. } \\
\text { 2. Menggunakan rumus logik } \\
\text { dengan alasan rumus tersebut } \\
\text { lebih mudah, tetapi tidak } \\
\text { dituangkan secara tertulis di } \\
\text { lembar jawabannya. } \\
\text { 3. Mengetahui rumus lain yang } \\
\text { dapat digunakan selain rumus } \\
\text { logik. }\end{array}$ & $\begin{array}{l}\text { 1. Melihat ke atas sambil } \\
\text { memegang kepalanya. } \\
\text { 2. Menggunakan rumus logik } \\
\text { dengan alasan rumus } \\
\text { tersebut lebih mudah, tetapi } \\
\text { tidak dituangkan secara } \\
\text { tertulis di lembar } \\
\text { jawabannya. } \\
\text { 3. Mengetahui rumus lain } \\
\text { yang dapat digunakan selain } \\
\text { rumus logik }\end{array}$ & $\begin{array}{l}\text { 1. Meletakkan kepala di atas meja } \\
\text { sambil melihat ke atas dan } \\
\text { menggerak-gerakan pulpen } \\
\text { yang dipegangnya. } \\
\text { 2. Menggunakan rumus logik yang } \\
\text { dianggapnya lebih mudah, } \\
\text { tetapi tidak menuliskan rumus } \\
\text { tersebut. } \\
\text { 3. Tidak mengetahui rumus lain } \\
\text { yang dapat digunakan selain } \\
\text { rumus logik. }\end{array}$ \\
\hline $\begin{array}{c}\text { Menyelesaikan } \\
\text { masalah sesuai } \\
\text { rencana }\end{array}$ & $\begin{array}{l}\text { 1. Melakukan perhitungan } \\
\text { dengan bersuara khususnya } \\
\text { pada saat perhitungan operasi } \\
\text { bilangan dan terlihat tanpa } \\
\text { hambatan dalam } \\
\text { mengerjakannya. } \\
\text { 2. Mampu menyelesaikan } \\
\text { masalah dengan benar dan } \\
\text { tepat. } \\
\text { 3. Langkah-langkah yang } \\
\text { disusun sesuai dengan } \\
\text { rencana sebelumnya. }\end{array}$ & $\begin{array}{l}\text { 1. Melakukan perhitungan } \\
\text { dengan corat-coret di kertas } \\
\text { lain. } \\
\text { 2. Dapat menyelesaikan } \\
\text { masalah } \\
\text { 3. Langkah-langkah yang } \\
\text { disusun sesuai rencana, } \\
\text { tetapi terdapat kekeliruan } \\
\text { pada perhitungannya. }\end{array}$ & $\begin{array}{l}\text { 1. Menyerah dan putus asa, karena } \\
\text { tidak sanggup lagi untuk } \\
\text { mengerjakannya. } \\
\text { 2. Tidak dapat menyelesaikan } \\
\text { masalah secara utuh, hanya } \\
\text { sebagian yang dikerjakan. } \\
\text { 3. Langkah-langkah yang disusun } \\
\text { belum sesuai dengan yang } \\
\text { direncanakan. }\end{array}$ \\
\hline $\begin{array}{c}\text { Melakukan } \\
\text { pengecekan } \\
\text { kembali } \\
\text { terhadap } \\
\text { semua langkah } \\
\text { yang } \\
\text { dikerjakan }\end{array}$ & $\begin{array}{l}\text { 1. Melihat kembali proses } \\
\text { penyelesaian yang dilakukan. } \\
\text { 2. Mensubtitusikan nilai x dan y } \\
\text { nya ke persamaan yang } \\
\text { diperoleh dan dibuktikan } \\
\text { dengan hasil pekerjaannya } \\
\text { secara tertulis. }\end{array}$ & $\begin{array}{l}\text { 1. Melihat kembali proses } \\
\text { penyelesaian } \\
\text { dilakukan. } \\
\text { 2. Mensubtitusikan nilai x dan } \\
\text { y ke persamaan yang } \\
\text { diperoleh, tetapi } \\
\text { menuliskan }\end{array}$ & $\begin{array}{l}\text { Melihat kembali proses } \\
\text { penyelesaian yang dilakukan, } \\
\text { walaupun tidak mempunyai } \\
\text { hasil yang pasti karena hanya } \\
\text { mengerjakan sebagian saja. }\end{array}$ \\
\hline
\end{tabular}

Tabel 1 dan tabel 2 menunjukkan bahwa gerak-gerik masing-masing subjek penelitian berbeda-beda dalam menyelesaikan masalah, khususnya dalam mengerjakan soal. Selain itu, aspek dari langkah-langkah pemecahan masalah pun berbeda antara laki-laki dengan perempuan, baik yang berkemampuan tinggi, sedang maupun rendah. Berikut ini dijabarkan temuan hasil penelitian dari langkah-langkah pemecahan masalah.

1. Memahami masalah

Semua subjek penelitian, baik laki-laki maupun perempuan dengan kemampuan tinggi, sedang dan rendah mengetahui informasi yang ada pada masalah, baik informasi yang ditanyakan maupun yang diketahui. Semua subjek menuliskan informasi yang Prima, Vol. 2, No. 2, Juli 2017, 137 - 147. 
diketahui dan ditanyakan, tetapi hanya LR dan PR yang tidak menuliskan informasi yang ditanyakan. Hal ini disebabkan karena siswa yang bekemampuan rendah belum memahami soal dengan baik sehingga tidak dapat membuat model matematika yang tepat dan sesuai dengan masalah yang diberikan atau dengan kata lain, tidak dapat membuat kaitan antara informasi yang diketahui dan ditanyakan, khususnya dalam model matematika. Selain itu, kurangnya ketelitian dalam membaca soal yang menyebabkan penulisan informasi yang ada tidak lengkap. Tetapi semua subjek mengetahui bahwa informasi yang ada sudah cukup.

2. Merencanakan pemecahannya

Semua subjek mengatakan bahwa merencanakan pemecahannya dengan menggunakan rumus logik, tetapi tidak ada yang menuliskan rencananya pada hasil pekerjaan tertulisnya. Subjek yang berkemampuan rendah, hanya dapat menyebutkan rumus tersebut, tetapi tidak mengetahui cara penggunaannya. Hal ini disebabkan karena siswa yang berkemampuan rendah tidak dapat menerapkan konsep-konsep dari rumus tersebut yang telah dipelajarinya.

3. Menyelesaikan masalah sesuai rencana

Dalam aspek ini, subjek yang memiliki kemampuan tinggi dapat menyelesaikan masalah dan hasil yang diperoleh tepat dengan langkah-langkah yang sesuai dengan rencananya. Sedangkan siswa yang memiliki kemampuan sedang dapat menyelesaikan masalah dengan langkah-langkah yang telah direncanakannya, namun pada proses perhitungan sering terjadi kekeliruan, khususnya pada operasi bilangnya, sehingga hasil yang diperoleh tidak tepat. Lain halnya dengan siswa yang berkemampuan rendah yang dapat menyelesaikan masalah, namun tidak secara tuntas diselesaikan, hanya sebagian saja, sehingga tidak mempunyai hasil. Penguasaan perhitungan dan ketelitian sangat diperlukan dalam tahap ini, karena kesalahan yang terjadi disebabkan oleh kurang telitinya dalam menyelesaikan masalah dan kekeliruan proses perhitungan yang dilakukan.

4. Melakukan pengecekan kembali terhadap semua langkah yang telah dikerjakan

Pada aspek ini, hanya PT yang menuliskan cara pengecekannya, sedangkan siswa lainnya tidak menuliskan cara mengeceknya terhadap hasil yang diperoleh. Aspek ini sangat penting dilakukan untuk lebih meyakinkan terhadap hasil yang diperoleh. Keterbiasaan siswa yang tidak memeriksa kembali setiap langkah yang dilakukan dan 
hasil jawaban yang diperoleh diduga menjadi salah satu penyebab hasil yang diperoleh tidak benar dan tidak tepat karena tidak melakukan tahapan pengecekan kembali.

\section{SIMPULAN DAN SARAN}

Berdasarkan hasil analisis dan pembahasan yang diperoleh maka dapat disimpulkan bahwa siswa dengan kemampuan tinggi baik laki-laki maupun perempuan memiliki langkahlangkah pemecahan masalah yang baik. Sedangkan siswa dengan kemampuan sedang, baik laki-laki maupun perempuan memiliki langkah-langkah pemecahan masalah yang cukup baik, karena pada proses perhitungan yang dilakukan masih terjadi kekeliruan yang menyebabkan hasil yang diperoleh tidak tepat. Lain halnya dengan siswa dengan kemampuan rendah. Siswa dengan kemampuan rendah, baik laki-laki maupun perempuan memiliki langkah-langkah pemecahan masalah yang kurang baik karena tidak dapat menyelesaikan masalah secara tuntas, sehingga tidak mempunyai hasil yang diperoleh.

Berdasarkan hasil penelitian yang dilakukan tentang kemampuan pemecahan masalah matematika, maka peneliti dapat mengemukakan beberapa saran sebagai berikut.

1. Guru hendaknya memfasilitasi kegiatan pembelajaran dengan membiasakan siswa mengerjakan soal matematika yang dapat meningkatkan kemampuan pemecahan masalah matematika siswa.

2. Guru sebaiknya mengetahui kemampuan pemecahan masalah siswa sehingga hal tersebut dapat digunakan sebagai evaluasi untuk mengurangi kesalahan serta memperbaiki proses pembelajaran.

3. Guru melatih siswa untuk memberikan alasan pada setiap jawaban yang disampaikan agar siswa terbiasa untuk mengaitkan setiap masalah dengan pengetahuan yang dimiliki.

4. Siswa sebaiknya selalu mengecek kembali jawaban yang telah diperolehnya melalui proses tertentu agar terhindar dari kesalahan. Selain itu, siswa harus menguasai operasi bilangan, agar tidak keliru dalam pengoperasiannya.

\section{DAFTAR PUSTAKA}

Afgani D, Jarnawi. (2011). Analisis Kurikulum Matematika. Jakarta: Universitas Terbuka. Aisyah, Nyimas. (2007). Pengembangan Pembelajaran Matematika SD. Jakarta: Depdiknas. Amirulloh, A.F \& Budiarto, M.T. (2012). Kemampuan Number Sense Siswa Kelas VII SMP Dilihat dari Perbedaan Jenis Kelamin. Volume 2 No. 1 Tahun 2013. 
http://ejournal.unesa.ac.id/index.php/mathedenusa/article/view/1438/baca-artikel (diakses 7 Desember 2013)

Arikunto, Suharsimi. (2013). Dasar-Dasar Evaluasi Pendidikan. Jakarta: Bumi Aksara.

Budhayanti, Clara Ika Sari. (2008). Pemecahan Masalah Matematika. Jakarta: Depdiknas.

Moleong, Lexy J. (2013). Metode Penelitian Kualitatif. Bandung: Rosda.

Nirmalitasari, Octa S. (2012). Profil Kemampuan Siswa Dalam Memecahkan Masalah Matematika Berbentuk Open-Start pada Materi Bangun Datar. Volume 1 No. 1 Tahun 2012. http://ejournal.unesa.ac.id/index.php/mathedunesa/article/view/247/baca-artikel (diakses 23 Desember 2013)

Putra, Nusa. (2012). Penelitian Kualitatif : Proses dan Aplikasi. Jakarta : Indeks.

Slameto. (2010). Belajar \& Faktor-Faktor Yang Mempengaruhi. Jakarta : Rineka Cipta.

Sugiman dan Yaya S. (2010). "Dampak Pendidikan Matematika Realistik terhadap Peningkatan Kemampuan Pemecahan Masalah Siswa SMP”. http://jims-b.org/wpcontent/uploads/2013/11/Full-IndoMS-JME-11-Sugiman.pdf (diakses 28 Desember 2013)

Sugiyono. (2009). Metode Penelitian Pendidikan. Bandung: Alfabeta.

Suherman, Erman. (2003). Strategi Pembelajaran Matematika Kontemporer. Bandung: JICA UPI.

Wena, Made. (2011). Strategi Pembelajaran Inovatif Kontemporer. Jakarta: Bumi Aksara 